\title{
McKinsey 7S Model for Supply Chain Management of Local SMEs Construction Business in Upper Northeast Region of Thailand
}

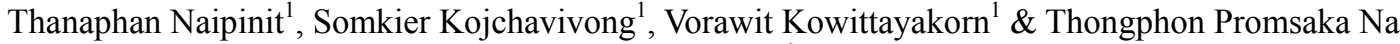 \\ Sakolnakorn $^{2}$ \\ ${ }^{1}$ Graduate School, North Eastern University, Thailand \\ ${ }^{2}$ Institute for Peace Studies, Prince of Songkla University, Thailand \\ Correspondence: Thanaphan Naipinit, Graduate School, North Eastern University, Khon Kaen, 40000, Thailand. \\ E-mail: chokanan_kk@hotmail.com
}

Received: December 17, 2013 Accepted: February 12, 2014 Online Published: March 26, 2014

doi:10.5539/ass.v10n8p35

URL: http://dx.doi.org/10.5539/ass.v10n8p35

\begin{abstract}
The purpose of this study is to study the successful business strategies and the guidelines for the management strategies of supply chain management of local small and medium enterprises (SME) construction shops. We use the McKinsey 7S model for the conception of this study by providing 400 questionnaires to participants and we also used focus groups for the management guideline. From the study we found that of the seven strategies (7S) in the model (structure, strategy, systems, styles, skill, staff, and shared values), most entrepreneurs scored highly in strategy; however, most entrepreneurs scored low in several areas: working with software applications, lack of outside training, and most entrepreneurs maintain command as the owner and do not give authority to others. In addition, the Thai government should create a policy by collaborating with Lao PDR to reduce some barriers of international trade to help SME construction shops in Thailand.
\end{abstract}

Keywords: McKinsey 7S model, supply chain management, local SMEs construction business

\section{Introduction}

Northeast Thailand holds a rather distinct place for most Thais. It is something akin to the nation's heartland and the region has a specific name, which is Isaan. Currently, the economy in Northeast is growing, and people have more money to build a new house or renovate. Reuters (2013) stated that economic growth in the northeast region reached 40 percent from 2007 to 2011, as opposed to 23 percent for the country and just 17 percent for greater Bangkok. Also, the number of private investment projects in the northeast rose 49 percent in 2012 from the previous year, with the total amount invested more than doubling to $\$ 2.3$ billion, according to the Bank of Thailand. Much of it is concentrated in property, from high-rise condominiums to town houses and shopping plazas.

Construction and property such as condominiums, houses and land property sales in the northeast are growing and many Korean, Vietnamese, and Japanese businesspeople live there because they have business in Lao PDR, which is close by (E-Saan Center Business and Economic Research, 2013). As construction and property business booming, construction business is the one sector that benefits from construction growth rate. However, small and medium construction businesses were affected with the arrival of large construction stores, such as HomePro, Global House, Thaiwatsadu, etc. These large stores have all types of construction equipment at a cheap price, and often greatly undermine local small and medium construction business, much like " a big fish eating a small fish," and many SMEs have gone out of business; however, still some SMEs in the construction business survived.

Supply chain coordination has become a critical success factor for supply chain management (SCM) and effectively improving the performance of organizations in various industries. Coordination refers to the integration of different parts of an organization or different organizations in a supply chain to accomplish a collective set of tasks and to achieve mutual benefits (Xue, Li, Shen, \& Wang, 2005). However, supply chain management is the backbone for any organization's competitive advantage, and can be the enabler to an organization's business strategy. But still today, many business leaders of local construction businesses do not fully understand the concept of supply chain management and the power that supply chain management offers in 
leveraging an organization and its customers a competitive advantage position. Shukla and Agarwal (2011) suggested that lack of a commonly accepted definition of supply chain management and the problems associated with supply chain activities makes the understanding of supply chain management difficult.

Local SME construction shops in northeast Thailand are involved in supply chain management because it is one of the many processes of business management, and can be the one strategy that can make them business survive and compete with larger construction shops. The purpose of this paper is to discover the successful business strategy for supply chain management, and the guidelines for the management strategies of supply chain management of successful local SME construction shops.

\section{Objective}

To study the successful business strategy of supply chain management of local SME construction shops.

To study the guidelines for the management strategies of supply chain management of local SME construction shops.

\section{Literature Reviews and Conceptual Framework}

Supply chain management was developed to express the need to integrate the key business processes, from end users through original suppliers (Oliver \& Webber, 1992, p. 63). Meeting customer due dates and time schedules is a critical concern for many manufacturing systems, because maintaining all customer schedules will greatly benefit and organization (Raman, 1995). Supply chain management it is a win-win business-based approach to the maintenance of relationships among enterprises, which has proven potential to improve companies overall performance including productivity, quality, safety, and environmental aspects and, therefore, their cost competitiveness and profit margin (Ofori, 2000).

The tools for supporting supply chain management are very important for many industrial sectors. Many supply chain management tools such as enterprises resource planning systems (ERP) exist on the market to support the integration of organization (Cheng, Law, Bjornsson, Jones, \& Sriram, 2010). The use of RFID (Radio Frequency Identification) tracking has considerably increased supply chain management during the past ten years (Hinkka \& Tätilä, 2013). Radio frequency identification and wireless sensor network technologies could improve the effectiveness and efficiency of just in time management (Shin, Chin, Yoon, \& Kwon, 2011).

Ciliberti, Pontrandolfo and Scozzi (2008) explained some interesting managerial implications for supply chain in SMEs. The focus is to implement information and communication activities and training initiatives, and to monitor supplier performance through the submission of checklists or by direct inspections. Geoffrey, Andrew and Sarah (2001) stated that SMEs' skills are explored in terms of their relevance to developing a more efficient supply network, if their current knowledge, skills, and attitudes are appropriate for achieving better supply chain integration. However, it is not just skill deficiencies, but also attitudes that can pose effective barriers to the efficient operation of supply chains. Construction is perhaps distinct from other industries in that all too often an adversarial culture dominates relationships between the parties in the project team. If partnerships are to succeed, they require trust, openness, and honesty, attributes that are sadly often in short supply in the construction industry.

As we mentioned above, supply chain management is involved in all activities of a business, and if the business does not the right strategy for managing itself, it will struggle to survive in this globalizing environment where larger, international companies are coming to developing countries and affecting local businesses. The McKinsey $7 \mathrm{~S}$ model is one concept that well known in the world; it analyzes how well an organization is positioned to achieve its intended objective. The model is most often used as a tool to assess and monitor changes in the internal situation of an organization. In this paper, we used the McKinsey 7S model (Robert, Thomas, \& Julien, 1980) as a conceptual framework. The McKinsey $7 \mathrm{~S}$ model involves seven interdependent factors: strategy, structure, systems, styles, skill, staff and shared values, as shown in Figure 1. 


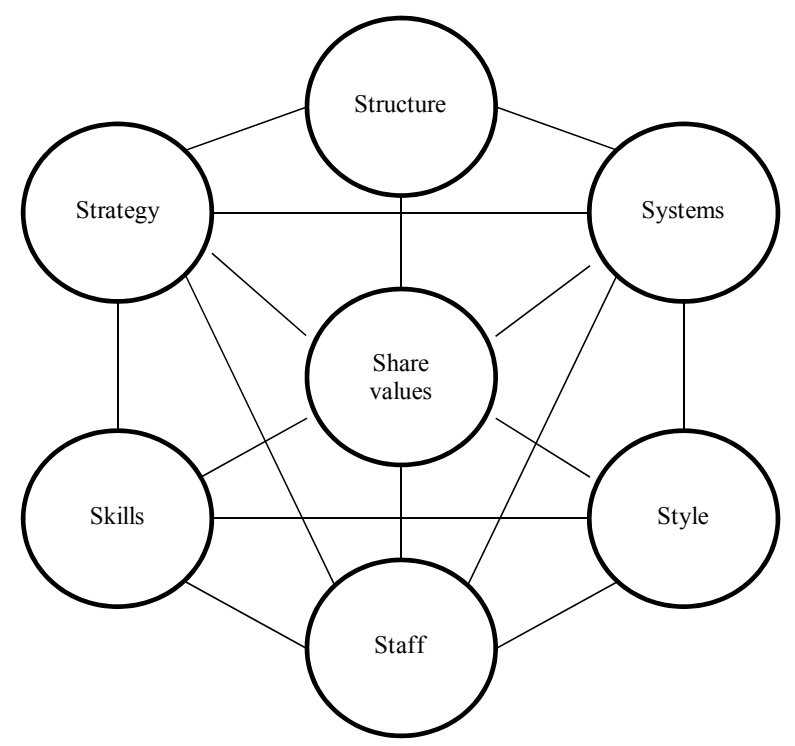

Figure 1. McKinsey 7S model

\section{Methodology}

In this paper we completed both quantitative and qualitative methods; for the quantitative method we provided 200 questionnaires to owners and entrepreneurs and provided 200 questionnaires to customers such as construction project leaders, construction foremen, and purchasing officers of construction sites who came to order and buy construction material at SME construction shops. The questionnaire used the Linkert scale and offered five answers: strongly agree, agree, moderately agree, disagree, and strongly disagree. The closed questionnaire was interpreted by dividing the question scale into a 5-point scale, as shown in Table 1.

Table 1. Significance of points

\begin{tabular}{ll}
\hline Average scores & Level of Significance \\
\hline $1.00-1.49$ & Lowest \\
$1.50-2.49$ & Low \\
$2.50-3.49$ & Moderate \\
$3.50-4.49$ & High \\
$4.50-5.00$ & Higher \\
\hline
\end{tabular}

In addition, we used the McKinsey 7S model to study the successful business strategy of supply chain management of local SME construction shop, and analyzed the data by using a mean standard deviation and raking the scores for important issues.

To study the guidelines for the management strategies of the supply chain management of local SME construction shops, we created a focus group by inviting 15 people, including a owners and entrepreneurs of SME construction shops, academicians who are experts in management strategy, construction project leaders, construction foremen, and purchasing officers of construction sites, for a discussion on strategic guidelines for SME construction shops, and we analyzed this data using content analysis and descriptive analysis.

In addition, the location of this study is in three provinces in upper northeast Thailand (Mukdahan, Nakhon Phanom, \& Nong Khai), and we selected this location because they are on the border between Thailand and Lao PDR, and many Lao customers come to Thailand to buy goods at construction shops and bring them back to do construction work in Lao PDR. The location of the study is shown in Figure 2. 


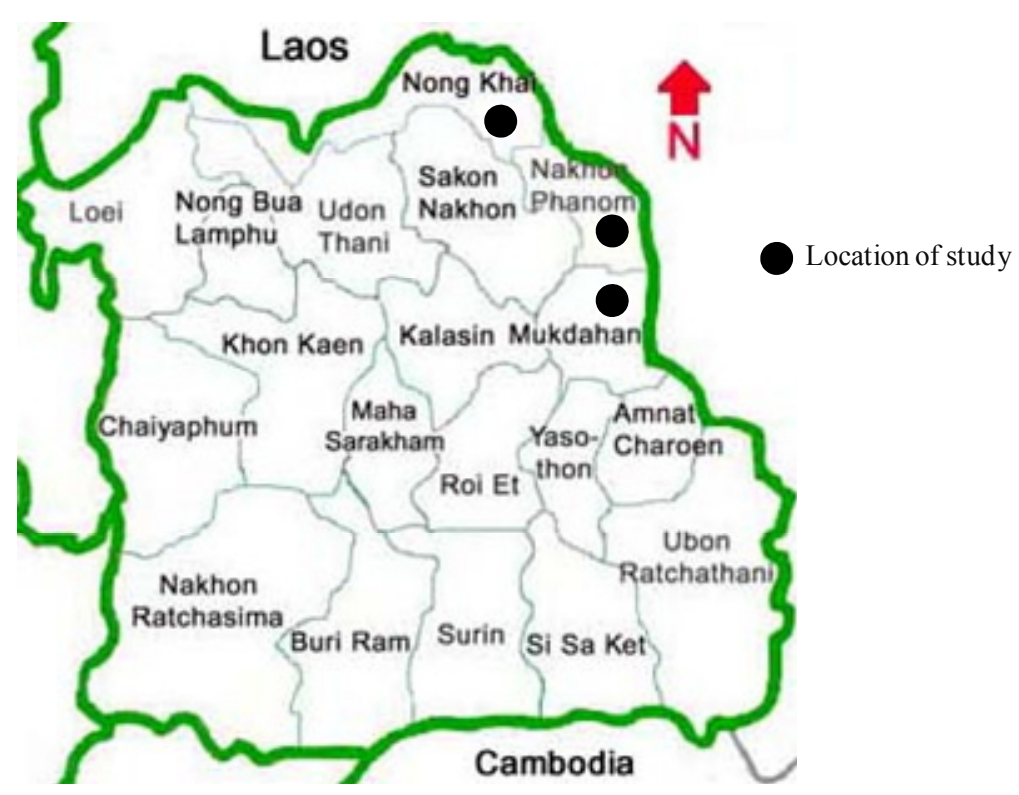

Figure 2. Location of study (http://www.trekthailand.net/p2/map.jpg)

\section{Results}

The seven strategies in the McKinsey 7S model are organization structure, management strategy, systems, styles, skill, staff, and shared values. These strategies are shown in Table 2.

Table 2. The analysis of the $7 \mathrm{~S}$ model

\begin{tabular}{|c|c|c|c|c|}
\hline \multirow[b]{2}{*}{ 7S model } & \multicolumn{3}{|c|}{ Opinion level } & \multirow[b]{2}{*}{$\begin{array}{l}\text { Level of significance } \\
\text { for strategy }\end{array}$} \\
\hline & $\bar{x}$ & S.D. & Interpret & \\
\hline \multicolumn{5}{|l|}{ Organization structure } \\
\hline $\begin{array}{l}\text { Clear job functions and responsibility in the organization } \\
\text { and employees understand their duties }\end{array}$ & 4.36 & 0.750 & High & 1 \\
\hline $\begin{array}{l}\text { Entrepreneurs use flexible strategies for working with their } \\
\text { employees }\end{array}$ & 4.28 & 0.736 & High & 2 \\
\hline Employees understand their responsibility and duty & 4.28 & 0.832 & High & 3 \\
\hline $\begin{array}{l}\text { Top management is concern with, advise on and command } \\
\text { every job function }\end{array}$ & 4.27 & 0.792 & High & 4 \\
\hline $\begin{array}{l}\text { Entrepreneurs rule the organization and every employee } \\
\text { understands this }\end{array}$ & 4.23 & 0.721 & High & 5 \\
\hline \multicolumn{5}{|l|}{ Management strategy } \\
\hline Entrepreneurs have an operation strategy and plan & 4.40 & 0.737 & High & 1 \\
\hline $\begin{array}{l}\text { Entrepreneurs have an organization strategy for business } \\
\text { expansion }\end{array}$ & 4.39 & 0.663 & High & 2 \\
\hline $\begin{array}{l}\text { Entrepreneurs have a business strategy plan for business } \\
\text { competitiveness }\end{array}$ & 4.27 & 0.707 & High & 3 \\
\hline \multicolumn{5}{|l|}{ Systems } \\
\hline Entrepreneurs have clear communication systems & 4.41 & 0.784 & High & 1 \\
\hline Entrepreneurs have a standardized system for work control & 4.32 & 0.813 & High & 2 \\
\hline Entrepreneurs have a standardize system for production & 4.21 & 0.860 & High & 3 \\
\hline \multicolumn{5}{|l|}{ Styles } \\
\hline Entrepreneurs set up modern styles for service and the & 4.26 & 0.785 & High & 1 \\
\hline
\end{tabular}




\begin{tabular}{|c|c|c|c|c|}
\hline \multirow[b]{2}{*}{ 7S model } & \multicolumn{3}{|c|}{ Opinion level } & \multirow[b]{2}{*}{$\begin{array}{l}\text { Level of significance } \\
\text { for strategy }\end{array}$} \\
\hline & $\bar{x}$ & S.D. & Interpret & \\
\hline \multicolumn{5}{|l|}{ interior design of shop } \\
\hline $\begin{array}{l}\text { SME construction shops have good images and the } \\
\text { customer remembers them }\end{array}$ & 4.25 & 0.742 & High & 2 \\
\hline $\begin{array}{l}\text { Employees have suitable work for patterns and organization } \\
\text { culture }\end{array}$ & 4.23 & 0.762 & High & 3 \\
\hline \multicolumn{5}{|l|}{ Skills } \\
\hline $\begin{array}{l}\text { Employees are service-minded and give good service to } \\
\text { customers }\end{array}$ & 4.41 & 0.696 & High & 1 \\
\hline $\begin{array}{l}\text { Employees are skilled in goods delivery and after-sale } \\
\text { service }\end{array}$ & 4.26 & 0.757 & High & 2 \\
\hline Employees are skilled in production and service & 4.10 & 0.789 & High & 3 \\
\hline \multicolumn{5}{|l|}{ Staff } \\
\hline Entrepreneurs have a good recruitment system & 4.25 & 0.733 & High & 1 \\
\hline Entrepreneurs promote drive and motivation in employees & 4.20 & 0.857 & High & 2 \\
\hline $\begin{array}{l}\text { Entrepreneurs provide good welfare and benefits to } \\
\text { motivate employees }\end{array}$ & 4.16 & 0.821 & High & 3 \\
\hline $\begin{array}{l}\text { Entrepreneurs provide personal development through } \\
\text { training }\end{array}$ & 4.04 & 0.826 & High & 4 \\
\hline \multicolumn{5}{|l|}{ Share value } \\
\hline $\begin{array}{l}\text { Management team and employees all together understand } \\
\text { the organization's success and the organization's target }\end{array}$ & 4.26 & 0.785 & High & 1 \\
\hline $\begin{array}{l}\text { Employees' feelings about collaboration are related to } \\
\text { organization effect and business success. }\end{array}$ & 4.17 & 0.903 & High & 2 \\
\hline Organization have activities for social responsibilities & 3.94 & 0.859 & High & 3 \\
\hline
\end{tabular}

From Table 2, in the analysis of the 7S model, we found that most of participants all did well in the management of their construction shop (high score). We found, however, that they scored the lowest in social responsibility, which is demonstrated by the fact that many of the organizations do not provide many activities to benefit their community and society, because they do not have the resources to do so; however, some of them donate to the temple in their community and they help with activities on Buddhist days.

To study the guidelines for the management strategies of supply chain management of local SME construction shops, we created a focus group by inviting 15 people for a discussion on strategic guidelines for SME construction shops as follow;

1) Organization structure: Entrepreneurs should to give some authority to employee leaders because most entrepreneurs manage their organization themselves, as the owners; they do not delegate authority to others, and sometimes this is the pitfall of this management style.

2) Management strategy: Entrepreneurs should develop their organization by using software to help management areas such as stock and inventory, accounting, orders, and purchases. This type of software can help them manage their materials precisely. In addition, in order to increase the bargaining power of SMEs, they can collaborate to order goods from big suppliers, which would give them the power to negotiate to reduce costs.

3) Systems: This issue is very important and can help an organization's work efficiency; for example, we found many construction shops use radio commander to help to communication between managers and employees, or between employees.

4) Styles: Entrepreneurs should embrace modern styles and technologies. For example, using GPS in trucks for delivering goods to customers can reduce the cost of transportation by saving time because of no lost drivers. In addition, the management styles of owners are very important because they have to perform many rule of the organization and how they handle various situations depends on their style of management. 
5) Skill: SME construction shops often do not send employees to training, most of them train by doing, so sending employees to train at outside organizations can help them gain more knowledge and can refresh their work attitudes. In addition, owners should also go to outside training in areas such as modern management or marketing strategy. This will help them be receptive to new ideas to develop their business and transfer knowledge to their employees.

6) Staff: Job development is important, and is completed by creating employee motivation using various tools. These tools include raises in income, greater benefits, and year-end bonuses. These could motivate the employees to work more efficiently and feel more responsibility to their organization.

7) Shared values: Creating a strong organizational culture and letting employees help set up the culture is important because it can help people work well and can make a business survive; however, a good organizational culture needs serious support from the owner and manager.

In addition, in order to use supply chain management for business success, SME construction shops should create production lines to produce material that is not difficult, for example, concrete blocks, and should provide free delivery if the customer orders a high volume. The material should be sent on time and the organization should guarantee that they will take back the product if it is substandard and the customer is unsatisfied. In addition, stock and inventory affects the material's quality; however, from the study we found that many shops do not maintain a good inventory, so they should design the store to have modern systems in order to promote easily accessed materials.

\section{Conclusion}

Supply chain management is the systematic, strategic coordination of traditional business functions and tactics across all business functions within a particular company and across businesses within the supply chain, for the purpose of improving the long-term performance of the individual companies (Mentzer, 2001). Therefore, supply chain is involved all activities of the business life cycle. Hines (2004, p. 76) stated that supply chain strategies require a total systems view of the links in the chain that work together efficiently to create customer satisfaction at the end point of delivery to the consumer. The main strategy to maintain customers of SME construction shops is social responsibility, because the relationships between the shops and the people in the community can create brand royalty for customers. In addition, Kotler and Lee $(2005$, p. 3$)$ state that corporate social responsibility is involved in helping the well-being of the community with concern to the use of resources and the management of the organization by not doing anything to affect the community.

Supply chain management can be useful to SME construction shops to improve work flow, help inventory and stock improvement, improve response time, reduce waste time, reduce activities cost, and improve customer service; however, tools, such as software packages, are needed to develop supply chain management. In addition, owners should set up their organization by delegating authority for some decisions to employee leaders, and divide the organization into a marketing department and logistic department, and give authority to those departments to provide convenience to the owner, so the owner will have more time to create new ideas for management. In addition, the information interaction between suppliers, construction shops and customers is also important, but this system needs modern tools such as computers, the Internet, e-mail, video calls, or management software systems.

Finally, the study site is close to the Thai-Lao border and since many Lao people came to buy construction materials in Thailand, the Thai and Lao government should collaborate to reduce barriers (such as immigration processes, customs processes, and tax policies) to promote international trade between countries. This will help Thai entrepreneurs to increase their income and revenue. In addition, Nanudorn et al. (2012) suggested that Thailand-Laos border trade strategic management should have only one unit and/or department with management authority, and one-stop service points should be created at custom departments to avoid long customs lines. Equipment such as X-ray trucks should be provided to support this one-stop service to increase convenience and effectiveness as a way to avoid a situation where traders circumvent the law by not declaring goods at customs.

\section{References}

Cheng, J. C. P., Law, K. H., Bjornsson, H., Jones, A., \& Sriram, R. (2010). A service oriented framework for construction supply chain integration. Automation in Construction, 19(2), 245-260. http://dx.doi.org/10.1016/j.autcon.2009.10.003

Ciliberti, F., Pontrandolfo, P., \& Scozzi, B. (2008). Investigating corporate social responsibility in supply chains:
A $\mathrm{SM}$
perspective.
Journal
of Cleaner
Production,
16(15),
1579-1588. 
http://dx.doi.org/10.1016/j.jclepro.2008.04.016

E-Saan Center Business and Economic Research. (2013). Isaan daily News. Retrieved October 20, 2013, from http://www.ecberkku.com/th/news3/994--23-.html

Geoffrey, B., Andrew, R. J., \& Dainty, S. M. (2001). Construction supply chain partnerships: Skills, knowledge and attitudinal requirements. European Journal of Purchasing \& Supply Management, 7, 243-255. http://dx.doi.org/10.1016/S0969-7012(01)00005-3

Hines, T. (2004). Supply chain strategies: Customer driven and customer focused. Oxford: Elsevier.

Hinkka, V., \& Tätilä, J. (2013). RFID tracking implementation model for the technical trade and construction supply chains. Automation in Construction, 35(1), 405-414. http://dx.doi.org/10.1016/j.autcon.2013.05.024

Kotler, P., \& Lee, N. (2005). Corporate social responsibility: Doing the most good for your company and your cause. New Jersey: Wiley \& Sons.

Mentzer, J. T., DeWitt, W., Keebler, J. S., Min, S., Nix, N. W., Smith, C. D., \& Zacharia, Z. G. (2001). Defining Supply Chain Management. Journal of Business Logistics, 22(2), 1-25. http://dx.doi.org/10.1002/j.2158-1592.2001.tb00001.x

Nanudorn, S., Phisanbutr, S., Buddhagarn, R., Phuboonbutr, T., \& Sakolnakorn, T. P. N. (2012). The Effectiveness of Thailand-Laos Border Trade Strategic Management. International Business \& Economics Research Journal, 11(5), 559-566.

Ofori, G. (2000). Greening the construction supply chain in Singapore. European Journal of Purchasing \& Supply Management, 6(3-4), 195-206. http://dx.doi.org/10.1016/S0969-7012(00)00015-0

Oliver, R. K., \& Webber, M. D. (1992). Supply-chain management: Logistics catches up with strategy. In M. Christopher (Ed.), Logistics: The Strategic Issues. London: Chapman Hall.

Raman, N. (1995). Minimum tardiness scheduling in flow shop: Construction and evaluation of alternative solution approaches. Journal of Operation Management, 12(2), 131-151. http://dx.doi.org/10.1016/0272-6963(94)00010-C

Reuters. (2013). Thailand's boom: To the northeast, the spoils. Retrieved October 20, 2013, from http://www.reuters.com/article/2013/06/16/us-thailand-northeast-idUSBRE95F00H20130616

Robert, H. W. Jr., Thomas, J. P., \& Julien, R. P. (1980). Structure is not organization. Business Horizons, 80(23), 14-26.

Shin, T. H., Chin, S., Yoon, S. W., \& Kwon, S. W. (2011). A service-oriented integrated information framework for RFID/WSN-based intelligent construction supply chain management. Automation in Construction, 20(6), 706-715. http://dx.doi.org/10.1016/j.autcon.2010.12.002

Shukla, R. K., \& Agarwal, A. (2011). Understanding of Supply Chain: A Literature Review. International Journal of Engineering Science and Technology, 3(3), 2059-2072.

Xue, X., Li, X., Shen, Q., \& Wang, Y. (2005). An agent-based framework for supply chain coordination in construction. Automation in Construction, 14(3), 413-430. http://dx.doi.org/10.1016/j.autcon.2004.08.010

\section{Copyrights}

Copyright for this article is retained by the author(s), with first publication rights granted to the journal.

This is an open-access article distributed under the terms and conditions of the Creative Commons Attribution license (http://creativecommons.org/licenses/by/3.0/). 